\title{
Journey to Death: Fictionalizing the Syrian Refugee Crisis in Khaled Hosseini's Sea Prayer
}

\section{Abdul Samad Kadavan}

\begin{abstract}
This paper explores the fictional representation of the Syrian refugee crisis in Khaled Hosseini's novel Sea Prayer (2018). The novel is considered a refugee narrative, examining the question of home, displacement, and the fateful journeys of the Syrian refugees. The novel depicts the heart-wrenching experiences of the refugee community in war-torn Syrian city Homs before and after the outbreak of the civil war in the country. Evoking the tragic death of Alan Kurdi, Hosseini vividly illustrates the various dimensions of the Syrian refugee crisis, including the outbreak of the civil war in Syria and the eventual birth of refugees, their homelessness/statelessness, perilous journey to escape the persecution, xenophobic attitudes towards them, and post-war trauma. This paper draws on postcolonial refugee narratives, the concept of journeys of non-arrival, memory, and trauma studies to elucidate its argument. The contention here is that the current crisis in Syria is also accounted for by analyzing the fictional refugee narratives. The unspeakable trauma is communicated through fiction, and Hosseini's novel depicts the dangers engulfed and the hope entrusted in the refugees' journeys.
\end{abstract}

\section{Keywords}

Refugee, Refugee Literature, Civil War, Displacement, Statelessness, Spaces of Nonarrival, Trauma. 


\title{
Journey to Death: Fictionalizing the Syrian Refugee Crisis in Khaled Hosseini's Sea Prayer
}

\author{
Abdul Samad Kadavan
}

\section{Introduction}

The refugee crisis has always been a pressing issue encountered by the entire humanity since time immemorial. One can hardly see any difference in the rate of refugee flow before and after the emergence of modern nation-states unless the motives behind the refugee productions. However, studies reveal persistent patterns in refugee movements, especially after World War I. Keely contends that the "refugee production is rooted in geopolitical structure" ("How Nation" 1). David J. Whittaker observes that "since 1945 some 50 to 60 million people have been uprooted and left their homes either voluntarily or involuntarily..." from “... Europe in the 1950s, Africa in the 1960s, Asia in the 1970s and 1980s and, once more, Europe, particularly since the 1990s" (Asylum Seekers 1). This paper seeks to address the Syrian refugee crisis, focusing on the journeys through the 'nonarrival spaces' undertaken by the desperate refugees. Refugee narrative as a fictional account is employed as a medium to perceive various dimensions of the crisis.

The current refugee crisis that we see in the Middle East, especially in Syria, has turned out to be the most consequential one in the history of humanity. It is undoubtedly assumed to be one of the grave repercussions of the 9/11 political tragedy, followed by the notorious 'War on Terror' led by the Bush regime in the United States of America. A decade later, Arab Spring exploded, aggravating the situation. Meanwhile, Syria has been undergoing a severe economic crisis as its regime's policy privileged only the urban elites. Moreover, its authoritarian regime entrenched its control over the masses. The frustrated middle class began to conduct peaceful protests against the government.

The regime's response towards the protest was mild initially as it took initiatives to hold talks with the protesters and consider their demands. However, the regime began to implement violent crackdowns on any form of anti-government expressions quite often. This hostile attitude of the regime led to bitter conflicts between the State and the civilians over the past ten years. Gradually, the nature of the conflict transformed from a 
rebellion against an oppressive regime into a sectarian civil war, opening doors to various Islamist networks and radical groups, including ISIS. Subsequently, Syria witnessed the world's most enormous wave of displacement in modern history. Claire Gallien has made it clear in his analysis of refugee literature and arts.

Four major geopolitical events have had deep and long-term destructive effects in Africa and the Middle East and their populations: the invasion of Afghanistan and the fall of the Taliban regime in 2001, the invasion of Iraq in 2003 and expansion of ISIS insurgency, the successive civil uprisings and revolutions in the Arab world leading to the beginning of the war in Syria in March 2011, and the fall of the Gaddafi regime in Libya in October. ("Forcing Displacement" 737)

More than 13 million people are now displaced in Syria, including 6.6 million refugees and more than six million internally displaced people ("Syria Emergency" 2021). Though the representations of refugees in literary texts can be traced back to antiquity, the present era of globalization and international conflict has created a sense of literary urgency, resulting in an abundance of new literary works devoted to describing refugee lives. Exit West (2017), written by Mohsin Hamid, A Land of Permanent Goodbyes (2018) by journalist turned novelist Atia Abawi, and The Silence and the Roar (2013) by Nihad Sirees are a few novels that vividly translate the subtleties and the entanglements of the Syrian refugee crisis into literature.

\section{Who Is a Refugee?}

Andrew E. Shacknove defines a refugee simply as "a person fleeing lifethreatening conditions" ("Who Is a Refugee?" 274). This definition helps distinguish a refugee from an immigrant. The latter is a person who willingly decides "to resettle to another country" (Martinez and Marquez 2014). However, Shacknove validates any possible changes to this definition as required by the context. For instance, the political and legal contexts demand identifying a refugee as "a person who has crossed an international frontier because of a well-founded fear of persecution" ("Who Is a Refugee?" 274). One can see slight differences in the state-approved definitions of refugees except that the majority follows the criteria formulated by the 1951 U.N. Convention. The Organization of African Unity (OAU) recognizes 'persecution' as a salient criterion of refugeehood (275). Valerie Anishchenkova emphasizes the aspect of 'vulnerability' in his definition of a refugee ("The Battle" 814). However, Shacknove contends that the absence of state protection is the basis of refugeehood (277).

Gallien observes that the term 'refugee' "marked a historical moment in Europe by fixing it into a legal category to designate politically persecuted people, thereby securing the right of refugee to political dissidents from the Eastern Bloc" ("Forcing Displacement" 738). The UNHCR convention held in July 1951 acknowledged a definition devised by its specialized agency. According to this definition, a refugee is a 
person who is outside his/her country of nationality or habitual residence; has a wellfounded fear of persecution because of his/her race, religion, nationality, membership of a particular social group or political opinion; and is unable or unwilling to avail himself/herself of the protection of that country, or to return there, for fear of persecution. (qtd. in Asylum Seekers 2)

Whittaker uses the term 'asylum seekers' instead of 'refugees' in common parlance. It has the potential to indicate "the fearful scenario of millions on the move, in turmoil and danger, deprived of a normal life because of conflict and persecution...." (1). In short, the idea of 'persecution' is closely associated with the idea of refugeedom. According to Whittaker, this idea "is generally based on persistent patterns of abuse, intervention, and intolerance." The UNHCR has set a formula that explicates various dimensions of the idea. It is "persecution $=$ the risk of individual serious harm + failure of state protection" (6). This formula stresses the role of the state as instrumental in the birth of refugees.

\section{Refugee Literature}

This study uses the terms 'narratives' and 'literature' interchangeably to designate the writings that entail any refugee experiences. Barbara Huber states that "there is no clear and official definition of the term 'refugee literature'." Hence, she resolves to use the term 'refugee literature' to "refer to texts which are written by, for, or about refugees" ("The Importance" 23). The website of the University of Chicago shows that the Department of English Language and Literature has designed a course titled "Literature of the Refugees" for undergraduate students. The course description considers the "texts written by and about refugees, economic migrants, stateless subjects, and camp denizens" (“25013 Literature”).

Gallien holds the view that "refugee literature can be taken to mean not only writing by refugees but also the publications of former refugees turned residents or nationals, as well as those who have not experienced forced displacement" ("Forcing Displacement" 742). The nature of this definition ensures creative diversity. Richard Black argues that "the field of 'refugee studies' has grown dramatically over the latter part of the twentieth century, in parallel with the significance of the phenomenon of forced migration itself" ("Fifty Years" 1).

\section{Refugee Literature and Postcolonial Studies}

A growing and substantial body of research seek to bring the 'refugee literature' under the ambit of postcolonial studies. April Shemak rephrases the term as 'postcolonial refugee narratives.' She defines the same "as prose narratives (novels, short stories, memoirs) by and about refugees fleeing nations of origin that have a European colonialism" (Abstract, "Postcolonial Refugee" 2013). In the biannual international symposium of the Scientific Interests Forum- the Middle East and Muslim Worlds held in Paris in early July 2017, Gallien had led a panel on "Refugee Literature." Considering 
the Syrian and Mediterranean refugee crisis, he decided to examine the literature and the arts of the last 15 years produced by Middle Eastern and African writers, filmmakers, and artists. He also concentrated on Arabic and/or Muslim literature as they have "still largely been left out of postcolonial discussions" ("Refugee Literature" 1).

Gallien contends that "refugee literature and arts in Europe and the USA are not a "scandal" for postcolonial studies but indeed have a lot to say concerning the violence and unevenness of the current world order". In his paper, he substantiates how the refugee literature and arts can often "constitute seminal experimentations with forms, genres, and languages, indicating, especially in an ecological vein, directions for postcolonial futures." He also invites the attention of contemporary postcolonial scholars to his definition of refugee poetics and aesthetics. He urges them to intervene in the "problematic modes of representation of forcibly displaced people..." (2). Drawing on Spivak, David Farrier considers the asylum seekers' candidacy "as the new subaltern who initiates the step beyond postcolonial discourse" (Postcolonial Asylum 5). Informed by Farrier's idea, Gallien argues that "refugee literature and arts which reinscribe subaltern voices and bodies are therefore good candidates for postcolonial analysis" ("Forcing Displacement" 742).

Refugee narratives expose what is not visible to mainstream media or what is deliberately kept invisible. They often depict undignified, violent, and absurd living conditions. Hence, according to Gallien, 'the term 'refugee' is a historical construction that privileged political and ideological considerations over economic and ecological ones." This observation puts the genre "as a mode of resistance and resilience against the perpetuation of colonial control, predation, and destruction, in "postcolonial" times" ("Refugee Literature" 3). He further points out that:

Refugee literature is not (only) a literature of despair that dwells on the moral hypocrisy of the West. Nor is it only a form of testimonial literature depicting traumatic events and an urgent intervention to respond to a fictional "crisis". In other words, its temporality reaches beyond the past, nostalgia, and trauma, but also beyond the present and its many urgencies.

Refugee narratives usually reflect upon intricate steps involved in the construction of a refugee. They illustrate the internal conflicts in a nation-state that eventually develop into a massive civilian protest accompanied by brutal state oppression giving birth to refugees as in Syria. Moreover, they vividly portray the state of being homeless/stateless in the wake of civil war followed by the perilous journeys undertaken by the displaced people seeking shelter. Depicting the xenophobic attitudes toward the refugee communities, criticizing the unstable state policies on refugee issues set by the host nations, and configuring a counter-narrative capable of challenging the liberal discourses of the modern nation-state are the characteristic features of refugee literature. It is to be noted that the refugee narratives of the $21^{\text {st }}$ century, both fictional and nonfictional, are super bound with dangerous journeys as well. 


\section{Refugee Literature and Trauma}

As Gallien rightly pointed out, refugee literature can be treated as a "form of testimonial literature" that depicts "traumatic events" of the refugees ("Refugee Literature" 5). There is no doubt that refugees go through severe trauma though it varies in degree according to the persons. J.D. Kinzie points out that "the refugees (may) have massive medical, prolonged unpredictable physiological, and psychological trauma, which not only occurs in their own country but often in refugee camps and in their host countries." He treats asylum seekers and refugees as 'traumatized communities' ("The Traumatic Lives" 44). Becoming a refugee entails one to be persecuted by any possible social and political institutions such as state or religion.

In trauma narratives, memory plays a significant role in facilitating readers' understating of events and experiences. Literary reflections of narrator's memories sharpen the traumatic experiences of the refugees. Nabokov, in his autobiography, Speak Memory (1951), defines memory as an "awakenings of consciousness as a series of spaced flashes, with the intervals between them gradually diminishing until bright blocks of perceptions are formed, affording memory a slippery hold" (3). The connecting thread is the stream of consciousness that informs memory and narrativity alike.

\section{Journeys of Nonarrival}

Refugees are destined to take up physical journeys from their homeland to foreign land/s. In their study of refugee flow into European nations, Maria and Weber designate the journeys of migrants and refugees across Europe as the journeys of 'nonarrivals' that take place across the 'spaces of nonarrival.' According to them, such journeys are "triggered by fear, journeys precipitated by violence and war, journeys that are interrupted, journeys that fail, journeys without destinations, and imagined arrivals that are never achieved." A comprehensive understanding of spaces of nonarrival in refugee narratives helps visualize the uncertainty, hopelessness, and insecurity felt by refugees. "Makeshift hotels, container homes, camps, asylum offices (and their accompanying lines), transport vehicles, boats, and beaches" constitute spaces of nonarrival. These spaces of interruption and barriers “...often prove to be either the place where the journey meets its fatal end or just another step forward yet other spaces of stasis and stagnation". Moreover, they "leave their inhabitants (refugees) devoid of a connection to space and time, instead of excluding them from the community and future" ("Touching Journeys" 1).

Journeys of refugees are more often than not disrupted and halted due to various reasons. The dynamics of the shifting politics of border control and border regimes in modern nation-states make the journeys of refugees more in trouble. For instance, the intensified detention and deportation of refugees in European countries as part of their security policies has worsened the refugee community's plight. Journeys of refugees in their narratives metaphorically recall Odyssey's journey. The only difference is that there is no promise of return in the refugee's journey. His destination is too far to reach. He 
often drowns in the sea. Gallien's observation that the Mediterranean Sea has turned out to be a cemetery shows precariousness in refugees' journeys.

\section{Sea Prayer}

Hosseini's novel Sea Prayer was first produced for public release as a virtual experience in collaboration with UNHCR, the Guardian, and Google on 1 September 2017. It got its print and e-book versions with dazzling illustrations by Dan Williams in the following year. The author's aim was primarily to mark the second anniversary of the death of Alan Kurdi, the third-year old Syrian boy. However, the novel became a tribute to thousands of refugees worldwide who lost their land, community, home, and whatnot (Bailey, Review 2018). Alan's lifeless body was washed up on the shore close to the southern Turkish resort of Bodrum. Along with his five-year-old brother, Galip, and mother, Rehen, he had drowned at sea just minutes after the family had got into an illequipped vessel. The refugee-turned family from the Syrian city Homs was desperately seeking shelter in Europe to escape the spaces of conflict. The narrator's family was fleeing State-sponsored persecution.

Sea Prayer is a refugee narrative as the core of the novel intensely addresses the refugee question. The novelist engages with a trauma story of a refugee family. Employing the canvass of the novel, he concretizes the subject of the refugee crisis, which often remains ignored due to highly politicized media coverage. Fiction is used as an appropriate vehicle for articulating the humanity of those affected. Hosseini used robust vocabulary and emotive language to invite global attention to the question. The novel is a "marvel for both its lyricism and its brevity, its ability to span generations and touch multiple narratives in such little space" (Baker, Review 2018). It generates ostensible reflections on human vulnerability and depicts a refugee's life without a shoreline. Fictionalizing the real tragedy meted out by Alan's family, Hosseini demonstrates the refugees in his novel not as illegals or culprits but as human beings who were forcefully displaced. Author's past as a displaced Afghan citizen may have morally motivated him to attend the refugee question urgently.

The narration of the novel carries the depth of the trauma a refugee is undergoing. The narrator's descriptions of the beautiful memories of the past in the first half of the novel indicate contingent traumas in the lives of displaced Syrians. The portrayal of the civil war in the novel invokes the terrorized minds of the displaced people. They know 'the skies spitting bombs. Starvation. Burials. (Sea Prayer 19). Children in war-torn Syria are supposed to play in 'bomb crater' as in a swimming hole' (24).

The setting of the novel is highly significant. The first half of the novel describes life in the pre-Civil war Syrian city Homs. The narrator of the novel, the father, is crying out his son Marwan, the fictional representation of Alan Kurdi, on the eve of his family's fateful journey through the Mediterranean Sea. He is very much sure about the dangers involved in the upcoming journey. As Maria and Weber pointed out, it is a journey of nonarrival through the spaces of nonarrival. The vehicle for the journey is underequipped. The destination is uncertain. There are neither safety nor security 
measures. However, he has decided to embark on a journey as he has been left with no alternative.

Memory is devised as a narrative technique to register the narrator's protest against the warmongering autocrats. The narrator takes the readers to his childhood memories, the most wonderful and beautiful ones in his life. However, his son cannot experience the same joy he had as the former is a refugee now. His family hails from Homs, a city in western Syria. Before the outbreak of the Syrian Civil War, Homs was a major industrial centre. It was the third-largest city in Syria after Aleppo to the north and the capital Damascus to the south. The city's population reflected Syria's broad religious diversity, composed of Sunni and Alawite Muslims and Christians. There were several historic mosques and churches in the city. Homs was a city rich with heritage. Such a city has now turned out to be a 'blighted city' (Sea Prayer 1) since 2011 with the explosion of the Syrian Civil War. It is now a site of near-daily confrontations between civilians and Syrian forces. Homs symbolizes the fallen capital of the Syrian revolution.

Homs has been a critical battleground in the uprising against Bashar al-Assad, the autocratic President of Syria. It was dubbed the "capital of the revolution" (Aswad 2020) after residents embraced the call to overthrow the President in early 2011. Much of the city fell under the control of the opposition. The government forces launched a campaign to retake the opposition strongholds, laying siege to districts once home to tens of thousands of people. Both the opposition and the ruling forces launched a series of bloodshed attacks which eventually displaced millions of citizens. The narrator is one of them. Aswad describes the devastating destruction caused by the heavy and relentless bombardment in the following words: "Most of the buildings have been cracked, occasionally crumbling. Civilians are often seen sitting in front of their destroyed homes meditating or crying silently" ("No services, no hope,").

The father recalls his unforgettable experiences with his toddler son. The memory of a village morning- waking up early and experiencing breeze in the olive trees- is still haunting him. The connecting thread here is the stream of consciousness that informs memory and narrativity alike. Memory has an essential association with fabulation, fictionality, and narrativity. The father wishes that his son had not been so young to forget the farmhouse, the soot of its stone walls, the creek, etc. He also wishes that his son remembered Homs city as he does. For, his memories let him survive the present and embolden him to encounter the casualties.

Nevertheless, young Marwan is devoid of those loving memories. The father continues to tell his son about the good old days of Homs city when religious harmony, peace, and communal amity flourished, and his mother and he walked around the Clock Tower Square. Those days are gone. The Clock Tower has become a symbol of antiregime resistance. The narrator seems that life and time like a 'dream' (Sea Prayer 19) now.

The second half of the novel showcases the war-torn Homs city. "First came the protests. Then the siege" (20). The tone of the narration turns gloomy. Now the skies above Homs city are spitting bombs. Farmland has become burial grounds. Citizens are 
starving. Children of the city are making a bomb crater into a swimming hole. The actual inhabitants of the city have been displaced. New refugees are born. They are preparing to embark on their journeys. They neither do have the travel kits nor the adequate vehicles. They have a proper destination neither.

Now the father is explaining to his son about the journey they are about to undertake. It is a journey of nonarrivals through the spaces of nonarrivals. The Mediterranean Sea is waiting for them. The only relief is that his family is not alone there. There are Afghanis, Iraqis, Somalis, Eritreans, and of course, Syrians. Every one of them is in search of a shelter, a home, and a state.

Meanwhile, the father heard somebody say that they are "uninvited" and "unwelcome" (Sea Prayer 33). Here, the narrator is vehemently criticizing the European nations building walls across their border to mitigate refugees 'illegitimate entrance into their lands. The refugee policies formulated by most of the states in Europe and the United States of America were disappointing to the refugee community across the globe.

\section{Conclusion}

Hosseini's Sea Prayer is a refugee narrative that manifests powerful articulations of the refugee crisis. He employed the verse novel as a diverse postmodern genre to experience refugee life more profoundly. The story draws on the technical aspects of poetry such as imagery, metaphors, and standard metric pattern to transcend the literal and leave an emotional imprint on the readers. The novelist successfully incorporated the destituteness of refugeedom in a series of short poems linked by topic, character, and plot. The novel is ambiguous, as if ever one can see the family's actual voyage and destination. The ambiguity can be interpreted as a call to action by readers, as an impetus to not just feel for Marwan and his family but to do something to ensure that Marwan's tale is one of ultimate triumph instead of tragedy.

\section{Works Cited}

Anishchenkova, Valerie. "The Battle of Truth and Fiction: Documentary Storytelling and Middle Eastern Refugee Discourse." Journal of Postcolonial Writing, vol. 54, no. 6, 2018, pp.809-820.

Aswad, Harun Al. "No services, no hope, just destruction in Syria's Homs." TRT WORLD, 8 December 2020, www.trtworld.com/magazine/no-services-no-hopejust-destruction-in syria-s-homs-42159. Accessed on 30 March 2021.

Bailey, Austin. "Sea Prayer by Khaled Hosseini Will Break Your Heart." Heifer International, 09 November 2018, www.heifer.org/blog/sea-prayer-review.html. Accessed on 15 April 2021.

Baker, Brianne. "Review of Sea Prayer by Khaled Hosseini." Columbia Journal, 2018, www.columbiajournal.org/review-sea-prayer-by-khaled-hosseini/. Accessed on 2/4/2021. 
Black, Richard. "Fifty Years of Refugee Studies: From Theory to Policy." The International Migration Review, vol. 35, no. 1, Special Issue: UNHCR at 50: Past, Present and Future of Refugee Assistance, Spring, 2001, pp. 57-78.

Blair, Tony. "Tony Blair's Speech on Asylum and Immigration.” The Guardian, 22 April 2005, www.theguardian.com/politics/2005/apr/22/election2005.immigrationand.

Davis, Rochelle. "Syria's Refugee Crisis." Great Decisions, published by Foreign Policy Association, 2015, pp. 65-76.

Farrier, David. Postcolonial Asylum: Seeking Sanctuary before the Law. Liverpool UP, 2011, p. 740.

Ferris, Elizabeth, and Kemal Kirisci. "The Context, Causes, and Consequences of Syrian Displacement." The Consequences of Chaos: Syria's Humanitarian Crisis and the Failure to Protect, Brookings Institution Press, 2016.

Gallien, Claire. "“'Refugee Literature": What Postcolonial Theory Has to Say." Journal of Postcolonial Writing, vol. 54, no. 6, 2018, pp. 721-726.

----. "Forcing Displacement: The Postcolonial Interventions of Refugee Literature and Arts." Journal of Postcolonial Writing, vol. 54, no. 6, 2018, pp. 735-750.

Hosseini, Khaled. Sea Prayer. Bloomsbury Publishing, Great Britain, 2018.

Huber, Barbara. "The Importance of Refugee Literature in the EFL Classroom: A Practical Guide to the Selection and the Teaching of Refugee Literature for and about Young Adults.” Diploma Thesis, Wien, 2018.

Keely, Charles B. "How Nation State Create and Respond to Refugee Flows." The International Migration Review, vol. 30, no. 4 Winter, Sage Publications, Inc. 1996, pp. 1046-1066, JSTORE, www.jstor.org/stable/2547603.

Kinzie, J.D. (44, "The Traumatic Lives of Refugees and Asylum Seekers." GPSolo, September/October, vol. 30, no. 5, published by American Bar Association, pp. 42-44, 2013.

Martinez, Michael, and Miguel Marquez. "What's the Difference between Immigrant and Refugee?" CNN US, July 16, 2014, www.edition.cnn.com/2014/07/15/us/immigrant-refugee-definition/index.html. Accessed on 01 May 2021.

Maskoun, Shahm. "Refugees are not the crisis. This is the crisis." UNHCR: The UN Refugee Agency, Innovation Service, "Refugees are not the crisis. It's the narratives we tell about them", www.unhcr.org/innovation/refugees-are-not-thecrisis-its-the-narratives-we-tell-about-them/. Accessed on 30 April 2021.

Nabokov, Vladimir. Speak, Memory: An Autobiography Revisited. Vintage International, 1989.

Operational Portal Refugee Situations. "Syria Regional Refugee Response.” 2011, https://data2.unhcr.org/en/about/. Accessed on 30 April 2021.

Ostrand, Nicole. Abstract of "The Syrian Refugee Crisis: A Comparison of Responses by Germany, Sweden, the United Kingdom, and the United States." Journal on Migration and Human Security, 2018, 
doi.org/10.1177/233150241500300301.

Pope, Paul James. “Constructing the Refugees as Villain.” World Affairs, vol. 180, no.3, Sage Publications, Inc. Fall 2017, pp. 53-71, JSTORE, www.jstor.org/stable/10.2307/26386898.

Shacknove, Andrew E. "Who Is a Refugee." Ethics, The University of Chicago Press, vol. 95, no. 2, Jan., 1985, pp. 274-284.

Shemak, April. Abstract of "Postcolonial Refugee Narratives." The Encyclopedia of Global Human Migration, edited by Immanuel Ness, Blackwell Publishing Ltd., 2013, doi.org/10.1002/9781444351071.wbeghm422.

Snow, Tom. "Visual Politics and the 'Refugee' Crisis: The Image of Alan Kurdi." Refuge in a Moving World: Tracing Refugee and Migrant Journeys across Disciplines, edited by Elena Fiddian-Qasmiyeh, UCL Press, 2020.

Stan, Corina. "A Life without a Shoreline: Tropes of Refugee Literature in Jenny Erpenbeck's Go, Went, Gone.” Journal of Postcolonial Writing, vol. 54, no. 6, 2018, pp. 795-808.

Stehle, Maria, and Beverly Weber. "Touching Journeys: Precarious Intimacies and Narratives of Nonarrival." Precarious Intimacies: The Politics of Touch in Contemporary Western European Cinema, Northwestern UP, 2020, JSTORE, www.jstor.org/stable/j.ctv14161gx.5.

The University of Chicago: Division of the Humanities English. "25013 Literature of the Refugee." www.english.uchicago.edu/courses/literature-refugee.

UNHCR: The UN Refugee Agency India. "Sea Prayer- education resources." www.unhcr.org/5c17c5fe4. Accessed on 2 April 2021.

UNHCR: The UN Refugee Agency. "Syria Emergency." 15 March 2021, www.unhcr.org/en- in/syria-emergency.html. Accessed on 30 April 2021.

Whittaker, David J. Asylum Seekers and Refugees in the Contemporary World. The Making of the Contemporary World, edited by Evans, Eric J, and Ruth Henig, Routledge, 2006.

\section{The Authors}

\section{Abdul Samad Kadavan}

Ph.D. Research Scholar,

Department of English and Comparative Literature.

Central University of Kerala, India

Email: samadkadavan@gmail.com

\section{The Article}

Date sent: 11/06/2021

Date revised: 18/09/2021

Date Accepted: 10/10/2021 